\title{
Social Aspects of Criminal Responsibility for Escape from Prison, Arrest, or Custody in the Criminal Legislation of the Foreign Countries
}

\author{
Aleksandr L. Zhuykov \\ Candidate of Legal Sciences, Associate Professor of Department of Criminal Law and Procedure, \\ Perm Institute for Economy and Finance, Russia, 614000, Kuybysheva Str.- 98a \\ Anna V. Zakharkina \\ Senior Lecturer of Department of Civil Law and Process, \\ Perm Institute for Economy and Finance, Russia, 614000, Kuybysheva St. - 98a \\ AnnaVladimirovna2009@yandex.ru
}

\section{Doi:10.5901/mjss.2015.v6n3s6p107}

\section{Abstract}

The article is devoted to the complex system study of legal regulation of criminal liability for escape from prison, arrest, and custody in the legislation of the foreign countries. The authors examine the model of the analyzed type of crimes in the Model Criminal Code for the CIS states, as well as the criminal codes of the CIS states. The article pays attention to the legal regulation of the examined types of crimes in the criminal codes of the European countries. Comparative analysis of the legislative structure of escape from prison or custody in the Model Criminal Code, criminal codes of the CIS countries, and a number of the European countries allowed the authors to formulate the following conclusion: setting of criminal liability for escapes from prison or custody is an objective necessity for legislator of a legal state in order to provide proper criminal law protection of goals and objectives of justice in the field of criminal and legal relations.

Keywords: criminal liability, escape from prison, Model Criminal Code for the CIS member states, foreign criminal legislation

\section{Introduction}

Criminal liability for escape from prison, arrest, or custody attracts the attention both of Russian and foreign scholarsjurists (Dunkel \& Pruin, 2009; Elliot \& Quirin, 2000; King Roy D. Kathleen Mc Dermott, 1995).

The Model Criminal Code for the CIS states is a recommendatory legislative act. It was adopted by resolution of the Interparliamentary Assembly of the CIS states in St. Petersburg on February 17, 1996.

In our opinion, the model of the analyzed type of crimes, which was proposed in the Model Criminal Code, is more perfect than that in the Criminal Code in 1996.

\section{Model Criminal Code for the CIS States and Criminal Codes of the CIS States}

First of all, the Model Criminal Code marked out crimes against justice as a separate chapter (Lozovitskaya, 2002). The vast majority of states took this recommendation, only the Criminal Code of Moldova does not have a relevant chapter, and Criminal Codes of Ukraine and Georgia set even relevant sections. The legislator of Moldova put crimes against justice to malfeasance. The immediate object of escape from prison or detention in the Model Criminal Code is closely connected with public relations on bringing to criminal prosecution and execution of sentences assuming deprivation of liberty.

The Model Criminal Code contains Article 340 "Evasion from serving a sentence of imprisonment" and Article 341 "Escape from prison or custody". If criminal liability for escape from prison is set in the codes of all states, the responsibility for avoiding punishment in the form of imprisonment is not provided only in the Criminal Code of Uzbekistan.

Disposition of Part 1 of Article 341 of the Model Criminal Code is defined as "escape from prison or custody, committed by a person serving a sentence or being in custody". It identifies two variants of the objective side of the escape: from prison or custody. There is no escape from arrest, although arrest as a form of punishment is set both in the Model Criminal Code (Article 55) and in most codes of the CIS countries, with the exception of the Criminal Code of 
Moldova and the Criminal Code of Turkmenistan. Such a definition of the objective side of escape seems to be more appropriate. The variant of escape from arrest is present only in the Criminal Code of the Russian Federation, the Criminal Code of Belarus and the Criminal Code of Kazakhstan. Most of the legislators of the countries of the CIS perceived the construction of the objective side of the Model Criminal Code. The crime is defined as formal, and the crime is considered to be over from the moment of escape. None of the Criminal Codes of the CIS countries provide socially dangerous consequences and the cause-and-effect relations between the act and the consequences. The act here is just such an action which has a pronounced strong-willed character. The crime is defined as misdemeanor.

The subjective side is represented by the fault in the form of a direct intent. No motive or purpose are identified in the legislative structure and are a necessary sign of the subjective side.

This is a crime with a special subject. The subject is a person sentenced to imprisonment or a person in relation to whom a preventive punishment in the form of custody is employed.

Part 2 of Article 341 of the Model Criminal Code of the CIS defines as aggravating features of the crime the following: 1) perpetration of a group of persons by prior agreement; 2) with use of violence dangerous to life or health of other persons, or with the threat of use of such violence; 3 ) with use of weapons or objects used as weapons. Most of the legislators of the CIS countries perceived these features as qualifying circumstances, but along with them the Criminal Codes of some countries mark out also the following: replication (the Criminal Code of Turkmenistan); way to escape by digging, as well as with damaging the technical means of protection (the Criminal Code of Ukraine); with inflicting actual or moderate bodily injury; carried out by a specially dangerous recidivist (the Criminal Code of Uzbekistan). It is recommended to recognize these as serious crimes.

The Model Criminal Code did not lay the foundation of release from criminal responsibility, but a number of codes contain such grounds in the notes to the relevant articles. So, the explanatory note to Article 336 of the Criminal Code of Kyrgyzstan determined that the person which voluntarily returned within three days from the date of the escape for the first time to prisons or custody, is to be released from criminal liability if the person did not commit a new crime, and if the escape was not connected to the acts provided in paragraph 2 of the Article.

The explanatory note to Article 358 of the Criminal Code of Kazakhstan defines the following conditions for release from criminal liability: firstly, the voluntary return within seven days from the date of the escape; secondly, not committing a new crime after escape; thirdly, absence of aggravating circumstances of the escape. With these signs present, the person is, certainly, released from criminal liability.

The explanatory note to Article 365 of the Criminal Code of Tajikistan leaves the issue of relief from criminal responsibility at the discretion of the investigating authorities and the court: "... a person may be released ....". The legislator states that the condition for release is voluntary return in three days term to prison, under arrest, or in custody.

In our view, the presence of such a foundation for relief from criminal responsibility has a positive criminological importance not only in terms of suppression and prevention of escapes, but also of other crimes.

Along with criminal responsibility for escape from prison or from custody, Article 340 of the Model Criminal Code establishes responsibility for avoidance of service of sentence, in the form of imprisonment. Disposition is formulated in the following form: avoidance of the person sentenced to imprisonment, which is allowed a short-term leave from the prison or is given a suspended sentence, of punishment after expiration of leave of delay.

The listed basic elements of crime are presented in all Criminal Codes of the CIS countries, with the exception of the Criminal Code of the Republic of Uzbekistan.

Analysis of the Criminal Code of the foreign countries shows that the legislature of Ukraine branches off the general trend; in Articles 389 and 390 it sets criminal responsibility for avoiding such punishments as fines, denial of the right to occupy certain positions or to be engaged in certain activities, correctional or community labour, as well as limitation of freedom. In addition, criminal responsibility in the Criminal Code of Ukraine is provided for escape from prison or custody (Article 393) and for escape from specialized medical institution (Article 394). This single exception, presented by Ukraine, only confirms correctness of the approach of the Model Criminal Code and the majority of the legislators of the $\mathrm{CIS}$ countries in the issue of setting criminal responsibility for escape from prison or custody, as well as for avoidance of service of sentence of imprisonment.

Thus, definition of signs of escape in the Model Criminal Code is more perfect than in the Criminal Code of the Russian Federation. In our opinion, the exclusion of such variant of the objective side, as "... from arrest" from the disposition of Part 1 of Article 313 of the Criminal Code of the Russian Federation is justified. We share the point of view of L.V. Lobanova about rationality of the legislator to introduce grounds for exemption from criminal responsibility in the explanatory note to Article 313 of the Criminal Code (Lobanova, 2000). We suggest reading the explanatory note as follows: "Note. A person who voluntarily returned within three days from the date of committing an escape for the first time to a prison or place of detention shall be released from criminal liability if the person did not commit a new crime, and the 
escape was not connected with actions, described in parts 2 and 3 of this Article".

\section{Criminal Legislation of the European Countries}

A similar approach is observed in the criminal legislation of a number of European countries. In the Criminal Code of the Republic of Poland dated 2001 in the chapter "Crimes against justice", the legislator sets responsibility for escape from prison in $\S 1$ of Article 242. The immediate object of crime is the interests of justice in the sphere of criminal legal relations. The objective side consists in a voluntary illegal self-liberation of a person sentenced to imprisonment on the grounds of decision of the court or other public authority. The legislator does not provide any consequences. The form of guilt is expressed by intention, while the motive and the purpose are not defined by the legislator. This is a crime with a special subject - a person sentenced to imprisonment.

In $\S 2$ of Article 242 of the Criminal Code of Poland the legislator set criminal responsibility for avoidance of service of imprisonment. The objective aspect is expressed in non-return of the prisoner who was granted a temporary permission to leave the institution into penal institution or place of custody. In $\S 3$ of this article the legislator gives grounds for relief from criminal responsibility: if the prisoner returns back to prison within three days after the established period.

The legislator includes escape from prison to less serious crimes, as the set forms of punishment are the following: fine, restriction of liberty, or imprisonment for up to two years. Responsibility for avoidance of service of imprisonment is reduced: fine, restriction of liberty, or imprisonment for up to one year.

In $\S 4$ of this article, the legislator sets the following qualificatory circumstances: conspiracy with other persons, use of violence or threats of violence, or infliction of harm to places of detention. Even this crime is less serious according to the category.

Article 243 of the Criminal Code of Poland sets criminal responsibility for release of the person sentenced to imprisonment or for assistance for escape. It is also a less serious crime. Thus, the legislator of Poland documented criminal responsibility both for escape, assistance for escape by other persons, and for avoidance of service of the sentence of imprisonment.

The approach of the legislator of Austria is somewhat different from the traditional. In section 21 "Criminal offences against justice", the 1974 Criminal Code of Austria establishes criminal responsibility for the release of prisoners in $\S 300$.

Herein, the direct object is the goals and purposes of justice in the field of criminal and legal relations. The objective side consists in release of a prisoner, kept in custody on the basis of the judgment or resolution of a court or administrative body, in inducement of escape or assistance for this. The subjective aspect consists in the intentional form of guilt; at that, the motive and purpose are inessential for qualification. The subject is general: it can be any person, except for the prisoner. Thus, in paragraph 2 of $\S 300$ the legislator indicates that the prisoner, inclining another person to release him or assist while escaping, is not punished in accordance with the first paragraph. This crime, in fact, is a special regulation according to crime, established in § 299 "Concealment". The objective aspect of concealment is expressed in helping another person, who committed an act which is prohibited under threat of punishment, intentionally abscond or avoid the punishment, fully or partially. Sanctions of these two crimes are identical: imprisonment for up to two years or a fine of up to 360 daily rates. The release of prisoners is a special case of concealment. Despite the fact that criminal responsibility for escape of a prisoner is not established in the Criminal Code of Austria, the presence of general and special regulations emphasizes the legislator's understanding of the need to protect the goals and objectives of justice by the means of criminal law.

In 1995 Criminal Code of Spain, section 20 "Crimes against the judiciary" includes chapter 8 "Violation of the sentence", where Article 468 defines criminal responsibility for the violation of one's sentence, security measures, detention, preventive measures of conduct or supervision. The regulation is not only very important to this chapter, but it also largely determines the legislative approach in general. Such a rule is quite rare for the criminal law of European countries. Sanctions of Article 468 are defined by the legislator defines as following: imprisonment for a term from 6 months to 1 year, if the person was appointed a measure of imprisonment or a fine for a sum of between 12 and 24 monthly salaries in all other cases. Binding of execution of sentence on the prisoner seems to be justified in the light of the principle of separation of authorities and independence of the judiciary.

Article 469 sets a special regulation according to Article 468. Escape from prison involving violence or intimidation of people, or participation in a riot is recognized as a crime. The immediate object of this crime is the goals and objectives of justice in the sphere of criminal and legal relations. An additional object may be physical integrity and health of staff of penal institutions, or order in these institutions. The objective aspect is expressed in escape from prison with use of violence or threat of violence, or commission of acts which disorganize the work of penitentiary institutions. The 
subjective aspect can be expressed only in the form of direct intention. At that, the motive and the purpose are not important for qualification. The subject of crime is special - a person sentenced to imprisonment or a person taken into custody. Analysis of these two regulations allows making a conclusion that in the case of non-violent escape, the criminal responsibility should be set according to Article 469, not Article 468. The legislator, in fact, increased the criminal responsibility for violent escape. Sanction of Article 469 has only one form of punishment - imprisonment for the term from 6 months to 6 years.

Article 470 establishes criminal responsibility for private persons who prepared an escape of a convict, a prisoner, or a detainee from the place of their detention or during their transportation. Part 2 of Article 470 provides responsibility for the same acts involving violence or threat of violence, as well as bribery. Part 3 of Article 470 softens responsibility for close relatives of convict, prisoner, or detainee. And Article 471 sets higher liability for officials and civil servants, responsible for transportation or protection of a convict, a prisoner, or a detainee, for preparing an escape, or assisting it.

Thus, in the Criminal Code of Spain there is a very orderly system of regulations (set out in a separate chapter), setting criminal responsibility both for escape of convicts, prisoners, and detainees and for assistance for escape of their close relatives, private persons, and public officials.

\section{Conclusions}

Thus, the comparative analysis of the legislative structure of escape from prison or custody in the Model Criminal Code and Criminal Codes of the CIS countries and some European countries shows the following:

1. Establishment of criminal responsibility for escape from prison or custody is an objective necessity for the legislator of a constitutional state in order to ensure adequate criminal law protection of the goals and objectives of justice in the sphere of criminal and legal relations.

2. In order to achieve the objectives of general and special prevention, the legislator should create grounds for release from criminal responsibility for escape. This step is common for most of the legislators of European countries and the CIS countries.

\section{References}

Dunkel F., Pruin I. (2009). Summary analysis of the national to the questionnaire related to the treatment of juvenile offenders /I European Rules for juvenile offenders subject to sanctions or measures. Strasburg, 2009. Chapter 3. $216 \mathrm{p}$.

Elliot C. \& Quirin F. (2000). Criminal Law. London. 94 p.

King Roy D. Kathleen Mc Dermott. (1995). The state of our Prisons. New-York.357 p.

Lozovitskaya G.P. (2002). General comparative legal commentary and comparative tables of the Criminal Codes of countries - members of the Commonwealth of Independent States (CIS). Saratov. Vol. 2. P. 37.

Lobanova, L.V. (2000). Crimes against justice: dissertation of Doctor of Legal sciences. Kazan.P. 268. 